\title{
Nutritive value of feather keratin meals for ruminants
}

\section{J.A. Strzetelski, J. Kowalczyk', Barbara Niwińska, K. Bilik and Katarzyna Maciaszek}

\author{
Research Institute of Animal Production, \\ Department of Animal Physiology and Nutrition \\ 32-083 Balice. Poland \\ 'The Kielanowski Institute of Animal Physiology and Nutrition, \\ Polish Academy of Sciences \\ 05-110 Jabtonna, Poland
}

(Received 4 May 1999; accepted 5 July 1999)

\begin{abstract}
Feather keratin meal (FM) or feather keratin meal with $10 \%$ blood (FBM) were produced by hydrolysis of hen feathers for $30-40 \mathrm{~min}$ at $143^{\circ} \mathrm{C}$ under $3 \mathrm{~atm}$. of steam pressure. The obtained product was dried initially at 110 then at $90^{\circ} \mathrm{C}$ for $5 \mathrm{~h}$ for FM and $7 \mathrm{~h}$ for FBM. FM and FBM contained 92.3 and $90.3 \%$ dry matter, and, respectively: 9.5 and $7.7 \%$ of ether extract, 3.2 and 3.9 ash and similar amounts of crude protein in both meals, $86.8 \%$, on a dry matter basis. Rumen protein degradability coefficients determined in situ were 0.30 and 0.32 and after in vitro digestion with pepsin intestinal digestibility of rumen undegradable protein determined by the mobile bag technique were 0.74 and 0.71 for FM and FBM, respectively. Digestibility of dry matter, crude protein and fat determined on young bulls by the difference method were $80.5,81.2$ and 60.6 for FM, and 80.0, 83.9 and 64.0 for FBM, respectively. FBM contained less leucine, isoleucine and arginine, but more histidine, methionine, phenylalanine, tyrosine and lysine compared to these amino acid contents in FM.

The nutritive value of $1 \mathrm{~kg} \mathrm{FM}$ and FBM expressed in INRA system units was: 1.16 and $1.11 \mathrm{UFL}$; 1.10 and 1.05 UFV; 563 and $551 \mathrm{~g}$ PDIN; 472 and $463 \mathrm{~g}$ PDIE; 425 and $407 \mathrm{~g}$ PDIA, respectively.
\end{abstract}

KEY WORDS: feather keratin meal, nutritive value, ruminants

\section{INTRODUCTION}

Feather keratin meal obtained by proper processing of different kinds of feathers appears to be a good source of protein in ruminant nutrition. However, the feather hydrolysis process differs depending on the type of raw matcrial, i.e. if it is 
hen, turkey, geese, duck or other types of feathers, since each of them needs appropriate specific technological parameters for obtaining a good quality product comparable to soyabean meal (Aderibigde and Church, 1983; Ryś, 1993). The obtained product should be characterized by low protein degradability in the rumen and high intestinal digestibility.

Studies on processing keratin-containing materials and their properties were started in Poland by Wójciak and Żebrowska (1964), who obtained a product of acceptable quality for animal nutrition. Wolski (1979) proposed the method of treating feathers with urea and steam under pressure. The obtained product was fed to young bulls with satisfactory results (Strzetelski et al., 1982). Feather keratin meals with or without the addition of blood are produced in this country by steaming at an elevated temperature under pressure. However, there is a lack of specific data enabling their proper use in diet formulation for ruminants according to the INRA system.

The aim of the present study was to estimate the nutritive value of feather keratin meal produced with or without the addition of blood as a source of protein for ruminants.

\section{MATERIAL AND METHODS}

Feather keratin meal (FM) or keratin meal with blood (FBM) were produced in the Offal Utilization Plant „Konspol Bis” in Słupca (Poland) by hydrolysis of hen feathers alone or with the addition of $10 \%$ blood for $30-40$ min at $143^{\circ} \mathrm{C}$ and 3 atm. of steam pressure. The obtained products were dried initially at 110 and at a final temperature of $90^{\circ} \mathrm{C}$ for $5 \mathrm{~h}$ for FM and $7 \mathrm{~h}$ for FBM in a Stroka Duke type destructor. Meals were analyzed for nutrient contents and amino acid composition. Degradation of protein in the rumen, intestinal digestibility of rumen undegradable protein and nutrient digestibility were determined. Soyabean oilmeal, containing $46.96 \% \mathrm{CP}$, was used as the comparative feed.

\section{Digestibility experiment}

Digestibility cocfficients of nutrients of keratin meals were estimated on 6 bulls of $380 \pm 20 \mathrm{~kg}$ body weight (BW) by the difference method after two 30-day periods of adaptation to the respective diets and 5 days of faeces collection.

The basic daily ration fed in two equal portions during the first period of the experiment consisted of ( $\mathrm{kg} /$ day): meadow hay, 1.0 ; concentrate mixture containing $17 \%$ crude protein, 4.7 ; supplemented with keratin meal, 0.4 . Keratin meal was mixed thoroughly with the concentrate mixture before feeding. The concentrate mixture contained $(\%)$ : soyabean oilmeal, 10; ground barley, 50; 
ground wheat, 10; wheat bran, 28; and mineral mixture, 2 . The basic ration in the second period was reduced to $75 \%$ and the amount of keratin meal was increased to $0.7 \mathrm{~kg} /$ day. Respective samples of feeds and faeces were analyzed for nutrient content.

\section{Protein degradability}

Three bulls of $420 \pm 20 \mathrm{~kg}$ BW equipped with rumen and duodenal cannulas were used for determining in situ protein degradability according to MichaletDoreau et al. (1987). The animals were fed twice a day at 8.00 and 16.00 with a diet composed of meadow hay and concentrate in a proportion of $1.4: 1$ containing $16.8 \% \mathrm{CP}$ on a dry matter basis.

Meals were ground using a size $0.75 \mathrm{~mm}$ sieve and samples of $3 \mathrm{~g}$ were placed in polyamide tissue $42 \mu \mathrm{m}$ mesh bags sized $7.5 \times 10 \mathrm{~cm}$. Twelve bags with samples for each incubation time were placed in the rumen for $2,4,8,16,24$ and $48 \mathrm{~h}$ for digestion. After digestion the bags were washed in a washing machine for $4 \mathrm{~min}$ three times and dried at $85^{\circ} \mathrm{C}$ for $48 \mathrm{~h}$ and analyzed for protein disappearance. Coefficients of protein degradability in the rumen were calculated according to Michalet-Doreau (1987) assuming rumen digesta outflow of $0.06 / \mathrm{h}$.

\section{Intestinal digestibility}

Intestinal digestibility of rumen udegraded protein was determined on the same 3 animals as for rumen degradability determination, using the mobile bag technique according to Peyraud et al. (1988). Residues of feeds after $16 \mathrm{~h}$ incubation in the rumen were digested for $2.5 \mathrm{~h}$ in $0.01 \mathrm{M} \mathrm{HCl}$ with a pepsin $(300-600 \mathrm{U} / \mathrm{l})$ solution at $\mathrm{pH} 2.0$ and temperature $38.5^{\circ} \mathrm{C}$. Fifteen bags $(6.5 \times 6 \mathrm{~cm})$ with $1.5 \mathrm{~g}$ of each feed were inserted into the duodenum of each animal and afterwards collected from the faeces. Residues were analyzed for nitrogen, and protein digested in the intestine was calculated according to Kowalski et al. (1995).

\section{Chemical analysis}

Proximate analysis of feeds and faeces was carried out according to AOAC (1990) methods, gross energy was calculated according to Hoffmann et al. (1971).

The amino acid content in keratin meals was determined after hydrolysis with $6 \mathrm{~N} \mathrm{HCl}$. Sulphur-containing amino acids were determined after oxidizing with a formic acid and hydrogen peroxide mixture.

Protein and encrgy values of keratin meals were estimated according to the IZ-INRA (1997) system using INWAR ver. 1.26 software (1995). 


\section{RESULTS}

Analysis of kcratin meal and keratin meal with blood revealed a relatively high and similar content of dry matter, crude protein and fat. Digestibility coefficients of dry matter and crude protein for both meals were above $80 \%$, of fat above $60 \%$. Crude protcin degradability in the rumen $(0.30$ and 0.32$)$ and intestinal digestibility $(0.74$ and 0.71$)$ were also similar for both meals (Table 1). Degradability in the rumen and intestinal digestibility determined for soyabean oilmeal protein as a comparative feed were 0.52 and 0.94 , respectively.

TABLE 1

Content and digestibility of nutrients, degradability in the rumen and intestinal digestibility of keratin meals

\begin{tabular}{|c|c|c|c|c|}
\hline & Dry matter & Crude protein & Ether extract & Ash \\
\hline \multicolumn{5}{|l|}{ Hen feather keratin meal } \\
\hline digestibility in vivo, \% & 80.5 & 81.2 & 60.6 & - \\
\hline degradability in the rumen & - & 0.30 & - & - \\
\hline intestinal digestibility & - & 0.74 & - & - \\
\hline \multicolumn{5}{|c|}{ Hen feather keratin meal with blood } \\
\hline $\begin{array}{l}\text { nutrient, \% } \\
\text { digestibility in vivo, \% }\end{array}$ & $\begin{array}{l}90.34 \\
800\end{array}$ & $\begin{array}{l}78.40 \\
83.9\end{array}$ & $\begin{array}{l}7.00 \\
64.0\end{array}$ & $\begin{array}{c}3.55 \\
-\end{array}$ \\
\hline $\begin{array}{l}\text { digestibility in vivo, \% } \\
\text { degradability in the rumen }\end{array}$ & $\begin{array}{c}0.0 \\
-\end{array}$ & 0.32 & - & - \\
\hline intestinal digestibility & - & 0.71 & - & - \\
\hline \multicolumn{5}{|l|}{ Soyabcan meal } \\
\hline nutrient, $\%$ & 89.04 & 46.96 & 1.51 & 6.48 \\
\hline degradability in the rumen & - & 0.52 & - & - \\
\hline intestinal digestibility & - & 0.94 & - & - \\
\hline
\end{tabular}

The nutritive value of keratin meal without blood expressed in INRA (1988) protein and energy units was slightly higher than that of meal with blood (Table 2).

TABLE 2

Nutritive valuc of keratin meals expressed in INRA (1988) system units per $1 \mathrm{~kg}$ of dry matter

\begin{tabular}{lcccccc}
\hline Fecd & UFL & UFV & PDIN & PDIE & PDIA & GE \\
& & & $\mathrm{g}$ & $\mathrm{g}$ & $\mathrm{g}$ & $\mathrm{MJ}$ \\
\hline Hen feather keratin meal (FM) & 1.16 & 1.10 & 563 & 472 & 425 & 1.41 \\
Hen feather keratin meal with blood (FBM) & 1.11 & 1.05 & 551 & 463 & 407 & 1.38 \\
\hline
\end{tabular}


The proportion of lysine and methionine in keratin meal with blood was higher than in keratin meal without blood by 7 and $20 \%$, respectively (Table 3 ). Both meals contained a high proportion of sulphur containing amino acids, particularly of cystine.

TABLE 3

Amino acid proportions in hen feather keratin meals with or without blood addition, $\mathrm{g} / 16 \mathrm{~g} \mathrm{~N}$

\begin{tabular}{lccccc}
\hline $\begin{array}{l}\text { Amino acid } \\
\text { g/16 g N }\end{array}$ & $\begin{array}{c}\text { Feather } \\
\text { kcratin meal } \\
\text { (FM) }\end{array}$ & $\begin{array}{c}\text { Feather } \\
\text { keratin meal } \\
\text { with blood } \\
\text { (FBM) }\end{array}$ & $\begin{array}{c}\text { Amino acid } \\
\mathrm{g} / 16 \mathrm{~g} \mathrm{~N}\end{array}$ & $\begin{array}{c}\text { Feather } \\
\text { keratin meal } \\
\text { (FM) }\end{array}$ & $\begin{array}{c}\text { Feather } \\
\text { keratin meal } \\
\text { with blood } \\
\text { (FBM) }\end{array}$ \\
\hline Asp & 6.08 & 6.28 & Leu & 8.44 & 7.88 \\
Tre & 4.01 & 4.12 & Tyr & 2.33 & 2.59 \\
Ser & 8.72 & 8.55 & Phe & 4.37 & 5.00 \\
Glu & 11.61 & 11.41 & His & 1.84 & 2.22 \\
Pro & 10.27 & 10.25 & Lys & 3.30 & 3.53 \\
Gly & 7.91 & 7.75 & Arg & 5.96 & 5.73 \\
Ala & 6.31 & 6.35 & Cys & 4.84 & 4.84 \\
Val & 7.13 & 7.12 & Met & 0.51 & 0.61 \\
lle & 4.83 & 4.61 & & & \\
\hline
\end{tabular}

\section{DISCUSSION}

Addition of blood to hen feathers resulted in a slightly lower dry matter content in the obtained FBM compared to FM, though both meals were dried under similar technological conditions. The content of crude protein in both meals recalculated on a dry matter basis was similar $(86.8 \%)$. Nevertheless, dry matter and crude protein content were in the range of values given in feed composition tables (DLG, 1997; IZ-INRA, 1997).

Both meals contained more fat and ash than reported in the above-mentioned tables, which could have had an influence on the increased energy value of both meals. According to the INRA system (IZ-INRA, 1997), keratin meal, obtained from feathers containing $3.5 \%$ fat, has lower energy and intestinal digestible protcin than the meals studied in the present experiment ( 7 to $9 \%$ fat). The reason for this could be that a higher level of fat in the diet depress protein and cellulose digestion (Kowalczyk et al., 1977). A similar interaction can be also observed comparing tabular values for meat meal $(50 \% \mathrm{CP})$ and high content of fat $(13.3 \%)$ with values for meat meal containing low level $(5.1 \%)$ of fat.

Coefficients of apparent digestibility of dry matter and protein obtained in the experiment for keratin meal with or without blood $(0.80-0.83)$ were lower than 
given in the tables of feed standards (0.86), (IZ-INRA, 1997). Protein degradability in the rumen of both FM and FBM was 0.30 and 0.32 , respectively, and was lower than given in feed standard tables but higher than reported by Veen et al. (1996). However, intestinal protein digestibility of both meals $(0.74$ and 0.71 , respectively) was higher than given in fecd standard tables $(0.53)$. These differences between the data obtained in our experiment and other authors could be caused by different types of raw material, e.g. hair or hen, turkey, duck or geese feathers used for production, as they require differentiated technological parameters for satisfactory hydrolysis during production of the respective meals (Aderibigde and Church, 1983; Ryś, 1993).

The amino acid composition of both studied keratin meals was similar and generally reflected differences between amino acid composition of keratin meal and blood meal. Blood addition changed some amino acid contents of keratin meal since the proportions of amino acids in blood and keratin meals differ.

\section{CONCLUSIONS}

The results of the experiment indicate that both feather keratin meals with or without the addition of blood are a good quality high protein feed for ruminants. The data obtained in this study applied to diet formulation cnable increasing the utility of feather keratin meals produced in the country as a source of protein for ruminants.

\section{REFERENCES}

Aderibigde A.O., Church D.C., 1983. Feather and hair meals for ruminants. III. Relationship between enzymatic or in vitro rumen digestibility and in vivo digestibility of diets containing feather or hair meals. J. Anim. Sci. 57, 483-494

AOAC, 1990. Association of Official Analytical Chemists. Official Methods of Analysis. 15th Edition. Arlington, VA

DLG., 1997. Futterwerttabellen, Wiederkauer. 7. Erweiterte und Uberarbeitete Auflage, Frankfurt am Main, pp. 150

Hoffmann L., Schiemann R.. Jentch W., 1971. Energetische Verwertung der Narhstoffe in Futterrationen. In: Energetische Futterbewertung und Energienormen. VEB Dte. Landw. Verlag, Berlin (DDR), pp. 118-167

INRA, 1988. Institut National de la Recherche Agronomique. Alimentation des Bovins, Ovins, Caprins. (R. Jarrige, Editor). Paris

IZ-INRA, 1997. Institute of Zootechnics. Standards of Cattle, Sheep and Goats Feeding (in Polish). Omnitech Press, Warszawa

Kowalczyk J., Ørskov E.R., Robinson J.J., Stewart C.S., 1977. Effect of fat supplementation on voluntary intake and rumen metabolism in sheep. Brit. J. Nutr. 32, 25I-257 
Kowalski Z.M., Pisulewski P.M.P., Peyraud J.L.. Kamiński J., 1995. The effect of dried outflow temperature on rumen protein degradability and intestinal digestibility of rumen undegraded protein of dehydrated grass and lucerne. Ann. Zootech. 44, Suppl. 1, 88

Michalet-Doreau B., Verité R., Chapoutot P., 1987. Methodologie de la degradabilité in sacco de I'azote des aliments dans le rumen. Bull. Tech.. C.R.Z.V. Theix, INRA, 69, 5-7

Peyraud J.L., Genest-Rulquin C., Verité R., 1988. Mesure de la digestion de l'azote des aliments dans l'intestin des ruminants par la technique des sachets mobiles. l. Evaluation de la quantite de matières azotées indigestibles en sachet des principaux. Reprod. Nutr. Develop. 28, 129-130

Ryś R., 1993. Keratins from offals as a source of feed protein (in Polish). Biul. inf. Inst. Zoot. 31 (3-4), $35-45$

Strzetelski J.A., Ryś R., Maciaszek K., Wolski T., Skraba B., 1982. The application of pelleted keratin-urea preparation and barley-urea (whole grain) in feeding bulls (in Polish). Acta Agr. Silv., Ser. Zoot, 21, 99-113

Veen W.A.G., Steg A., Hindle W.A., Flachowsky G., Kamphues J., 1996. Determination of protein value of feather meal for ruminants. Proceedings of the workshop: Unconventional Feedsuffs. Landbanforschung-Volkenrode, Sonderheft 169, 209-212

Wolski T. 1979. Preparation of granulated feed from urea and feathers (in Polish). Przem. Spoz.. 33, 302-303

Wójciak M., Żebrowska T., 1964. Investigations on keratins. X. Solubility and amino acid composition of the proteins of keratin meals (in Polish). Rocz. Nauk Rol. 84-B, 41-49

\section{STRESZCZENIE}

\section{Wartość pokarmowa mączek keratynowych z piór dla przézuwaczy}

Mączkç keratynową z piór (FM) i mączkę keratynową z piór z dodatkiem 10\% krwi (FBM) wyprodukowano przcz hydrolizę piór kurzych z parą wodną pod ciśnieniem 3 at. przy temperaturze $143^{\circ} \mathrm{C}$ w ciagu $39-40 \mathrm{~min}$. Otrzymany po hydrolizie produkt suszono przez 5 (FM) i 7 (FBM) godz. w temperaturze początkowej 110 i końcowej $90^{\circ} \mathrm{C}$. FM i FBM zawicrały 92,3 i $90,3 \%$ suchej masy i odpowicdnio, 9.5 i 7,7\% ckstraktu eterowego; 3,2 i 3,9 popiołu i jednakową ilość $-86,8 \%$ bjałka ogólnego w suchej masic.

Współczynniki rozkładu białka w żwaczu oznaczone metodą in situ wynosiły $0,30 \mathrm{j} 0,32$, a jelitowej strawności białka nie rozłożonego w żwaczu i trawionego pepsyna, oznaczone metodą mobilnych woreczków, wynosiły 0.74 i 0,71, odpowiednio dla FM i FBM. Strawność suchej masy, białka ogólnego i ekstraktu eterowego oznaczona na buhajkach metodą różnicową wynosiła odpowiednio dla FM 80,5; 81,2 i $60,6 \%$, a dla FBM 80,0;83,9 i 64,0\%. FBM zawierała mniej leucyny, izoleucyny i argininy, natomiast więcej histydyny, metioniny, fenyloalaniny, tyrozyny i lizyny w porównaniu z zawartością tych aminokwasów w FM.

Oznaczona wartość pokarmowa 1 kg FM i FBM, wyrażona w jednostkach przyjętych w systemic INRA, wynosiła odpowiednio: 1,16 i 1,11 JPM; 1,10 i 1,05 JPZ; 563 i 551 g BTJN; 472 i 463 g BTJE oraz 425 i $407 \mathrm{~g}$ BTJP. 